\title{
UJI EFEK DAUN KEMANGI (Ocimum basilicum L.) TERHADAP PENYEMBUHAN LUKA INSISI PADA KELINCI (Oryctolagus cuniculus)
}

\author{
${ }^{1}$ Nurul Fitri Ramdani, ${ }^{2}$ Christi Mambo, ${ }^{2}$ Jane Wuisan \\ ${ }^{1}$ Kandidat Skripsi Fakultas Kedokteran Universitas Sam Ratulangi Manado \\ ${ }^{2}$ Bagian Farmakologi dan Terapi Fakultas Kedokteran Universitas Sam Ratulangi Manado \\ Email : nurulfitriramdani@yahoo.com
}

\begin{abstract}
Background and objectives : Medicinal plants have long been known and used in Indonesia, one of them being basil leaves (Ocimum basilicum L). Basil leaves contain flavonoid with anti-inflammatory properties that helps to reduce pain and swelling around wound. This study aimed to determine the effect of basil leaves on healing incision wound in rabbits. Methods: This current study is an experimental study using four rabbits as test animals. Three centimeters long and $0.3 \mathrm{~cm}$ deep incision wound were made on both the right side and the left side of the back. Incision wound on the right side of the back are treated with crushed basil leaves while the wounds on the left side of the back are left untreated, covered only with sterile gauze. Observations were carried out for two weeks with observe changes of the injuries in macroscopic length. Results: In the examination performed on the $14^{\text {th }}$ day after incision were made, a reduction in wound size were observed. In the intervention wound, complete closure has not yet occurred, but the length of the wound is shorter and wound surface has started to blend with the surrounding tissues. Crusts are observed on the wound surface. In control wounds, a reduction in size is observed, with slight red coloration in the center of the wound. Conclusion: From the result of the study of effects of crussed basil leaves on the healing incision wound on rabbits, the length of the incision wound which were given crushed basil leaves reduced faster than the wounds which were left untreated. Keywords: Wound healing, incision wounds, basil leaves.
\end{abstract}

\begin{abstract}
ABSTRAK
Latar belakang dan tujuan : Bangsa Indonesia telah lama mengenal dan menggunakan tanaman berkhasiat obat, salah satu tumbuhan alam di Indonesia adalah daun kemangi (Ocimum basilicum L). Daun kemangi memiliki kandungan flavonoid bersifat anti inflamasi yang dapat mengurangi rasa sakit apabila terjadi pendarahan atau pembengkakan pada luka. Penelitian ini bertujuan untuk mengetahui efek pemberian daun kemangi terhadap penyembuhan luka insisi pada kelinci. Metode : Penelitian ini merupakan penelitian eksperimental dengan menggunakan empat ekor kelinci sebagai hewan uji. Punggung kanan dan kiri kelinci diinsisi sepanjang $3 \mathrm{~cm}$ dan kedalaman 0,3 cm. Luka pada punggung kanan diberi daun kemangi sedangkan luka pada punggung kiri tidak diberi perlakuan hanya ditutup dengan kasa steril. Pengamatan dilakukan selama dua minggu dengan melihat perubahan panjang luka secara makroskopik. Hasil : Pada hari ke-14, luka yang diberi daun kemangi menunjukkan luka mulai menutup belum sempurna, kerak masih menempel, panjang luka semakin pendek dan tampak permukaan luka sudah mulai menyatu dengan kulit sekitar. Pada luka yang tidak diberi daun kemangi terlihat sedikit mengecil namun luka masih berwarna merah di bagian tengah. Kesimpulan : Dari hasil penelitian uji efek daun kemangi terhadap penyembuhan luka insisi pada kelinci didapatkan bahwa panjang luka yang diberi daun kemangi lebih cepat mengecil dibandingkan dengan panjang luka yang tidak diberi daun kemangi
\end{abstract}

Kata Kunci : penyembuhan luka, luka insisi, daun kemangi. 


\section{PENDAHULUAN}

Bangsa Indonesia telah lama mengenal dan menggunakan tanaman berkhasiat obat sebagai salah satu upaya dalam menanggulangi masalah kesehatan. Pengetahuan tentang tanaman berkhasiat obat berdasar pada pengalaman dan keterampilan yang secara turun temurun telah diwariskan dari satu generasi ke generasi berikutnya. ${ }^{1}$ Tumbuhan obat juga banyak dimanfaatkan sebagai bahan dasar pembuatan obat karena efisien, murah, dan mudah didapatkan. ${ }^{2}$

Daun kemangi (Ocimum basilicum L) merupakan salah satu tumbuhan alam yang mudah diperoleh di Asia seperti di Indonesia. ${ }^{3,4}$ Daun Kemangi berpotensi sebagai anti mikroba, anti inflamasi, antioksidan dan analgesik. ${ }^{5,6}$ Daun kemangi memiliki kandungan flavonoid bersifat anti inflamasi yang dapat mengurangi rasa sakit apabila terjadi pendarahan atau pembengkakan pada luka. Selain itu, flavonoid bersifat sebagai antibakteri dan antioksidan yang dapat meningkatkan kerja sistem imun dan membantu proses penyembuhan luka. ${ }^{7,8}$

Daun kemangi bukan hanya dikenal sebagai makanan saja, tetapi secara empiris telah digunakan masyarakat dalam pengobatan tradisional untuk berbagai macam penyakit di Indonesia. Salah satunya adalah sebagai obat alternatif dalam membantu penyembuhan luka.

Luka adalah hilang atau rusaknya sebagian jaringan tubuh, keadaan ini dapat disebabkan oleh trauma benda tajam atau tumpul, perubahan suhu, zat kimia, ledakan, sengatan listrik, atau gigitan hewan. ${ }^{9}$ Luka tidak dapat dibiarkan sembuh sendiri karena luka yang tidak dirawat dapat menyebabkan komplikasi seperti infeksi dan pendarahan. $^{10}$

Penyembuhan luka merupakan suatu proses yang kompleks, tetapi umumnya terjadi secara teratur. Proses penyembuhan luka terbagi atas 3 fase yaitu fase inflamasi, fase proliferasi, dan fase maturasi (remodeling). ${ }^{11}$ Salah satu contoh paling sederhana pemulihan luka adalah penyembuhan suatu insisi bedah yang bersih, tidak terinfeksi, dan dijahit dengan baik, proses ini disebut dengan penyembuhan primer ${ }^{12}$

Berdasarkan data dan informasi di atas, maka penulis ingin melakukan penelitian untuk mengetahui apakah daun kemangi mempunyai efek terhadap penyembuhan luka.

\section{METODOLOGI PENELITIAN}

Penelitian ini merupakan penelitian eksperimental dilakukan di Laboratorium Farmakologi Fakultas Kedokteran Universitas Sam Ratulangi Manado pada bulan September 2013 sampai bulan Januari 2014.

Pembuatan luka dilakukan pada empat ekor kelinci dewasa. Bulu di punggung kanan dan kiri dicukur secara hati-hati. Daerah yang sudah dicukur bulunya kemudian dibersihkan dengan alkohol 70\% ditunggu hingga kering dan dilakuan anastesi dengan lidokain $\mathrm{HCl}$ 2\%. Setelah itu masing-masing kelinci dibuat luka insisi pada daerah punggung kanan dan kiri dengan menggunakan pisau cutter, masingmasing satu luka, ukuran $3 \mathrm{~cm}$ dengan kedalaman $0,3 \mathrm{~cm}$. Luka pada punggung kiri tidak diberi lumatan daun kemangi, hanya ditutup dengan kain kasa steril untuk melihat penyembuhan luka yang terjadi secara alamiah. Sedangkan luka pada punggung kanan diberi lumatan daun kemangi kemudian ditutupi dengan kain kasa steril untuk melihat efek lumatan daun kemangi terhadap penyembuhan luka. Setelah itu luka kontrol dan luka perlakuan diperhatikan perubahan panjang luka yang terjadi setiap hari. Setiap penggantian lumatan daun kemangi, luka pada punggung kanan dan kiri dibersihkan dengan menggunakan aquades yang disemprotkan dengan menggunakan jarum suntik secara perlahan, kemudian dikeringkan dengan menekan kain kasa steril secara perlahan di kedua luka tersebut. Perkembangan pengamatan diamati setiap hari selama dua minggu. 


\section{HASIL DAN PEMBAHASAN}

Penelitian ini bertujuan untuk mengetahui efek pemberian daun kemangi terhadap penyembuhan luka insisi pada kelinci. Penelitian ini dilakukan untuk melihat perbedaan gambaran makroskpik antara luka yang diberi daun kemangi atau luka perlakuan dengan luka yang tidak diberi daun kemangi atau luka kontrol.

Pada hari pertama pembuatan luka, terlihat adanya darah yang keluar sebagai tanda bahwa kulit mengalami cedera akibat terputusnya pembuluh darah, maka tubuh berusaha menghentikannya dengan cara vasokonstriksi, pengerutan ujung pembuluh darah yang putus (retraksi) disertai reaksi hemostasis. Hemostasis terjadi karena trombosit yang keluar dari pembuluh darah saling melengket, dan bersama jala fibrin yang terbentuk, membekukan darah yang keluar dari pembuluh darah. Pemberian daun kemangi dan kasa steril membantu menghalangi keluarnya darah secara berlebihan. $^{9}$

Tabel 1. Perbandingan Panjang Luka Pada Punggung Kelinci

\begin{tabular}{|c|c|c|c|c|c|c|c|c|}
\hline \multirow{2}{*}{$\begin{array}{c}\text { Hari } \\
\text { ke- }\end{array}$} & \multicolumn{2}{|c|}{ Kelinci A } & \multicolumn{2}{c|}{ Kelinci B } & \multicolumn{2}{c|}{ Kelinci C } & \multicolumn{2}{c|}{ Kelinci D } \\
\cline { 2 - 9 } & Kiri & Kanan & Kiri & Kanan & Kiri & Kanan & Kiri & Kanan \\
\hline 1 & $3 \mathrm{~cm}$ & $3 \mathrm{~cm}$ & $3 \mathrm{~cm}$ & $3 \mathrm{~cm}$ & $3 \mathrm{~cm}$ & $3 \mathrm{~cm}$ & $3 \mathrm{~cm}$ & $3 \mathrm{~cm}$ \\
\hline 2 & $2,9 \mathrm{~cm}$ & $2,8 \mathrm{~cm}$ & $2,9 \mathrm{~cm}$ & $2,8 \mathrm{~cm}$ & $2,9 \mathrm{~cm}$ & $2,8 \mathrm{~cm}$ & $2,9 \mathrm{~cm}$ & $2,8 \mathrm{~cm}$ \\
\hline 3 & $2,7 \mathrm{~cm}$ & $2,5 \mathrm{~cm}$ & $2,8 \mathrm{~cm}$ & $2,7 \mathrm{~cm}$ & $2,7 \mathrm{~cm}$ & $2,6 \mathrm{~cm}$ & $2,8 \mathrm{~cm}$ & $2,6 \mathrm{~cm}$ \\
\hline 4 & $2,5 \mathrm{~cm}$ & $2,4 \mathrm{~cm}$ & $2,7 \mathrm{~cm}$ & $2,5 \mathrm{~cm}$ & $2,5 \mathrm{~cm}$ & $2,4 \mathrm{~cm}$ & $2,7 \mathrm{~cm}$ & $2,4 \mathrm{~cm}$ \\
\hline 5 & $2,4 \mathrm{~cm}$ & $2,2 \mathrm{~cm}$ & $2,6 \mathrm{~cm}$ & $2,0 \mathrm{~cm}$ & $2,2 \mathrm{~cm}$ & $2,1 \mathrm{~cm}$ & $2,5 \mathrm{~cm}$ & $2,2 \mathrm{~cm}$ \\
\hline 6 & $2,1 \mathrm{~cm}$ & $2,0 \mathrm{~cm}$ & $2,5 \mathrm{~cm}$ & $1,8 \mathrm{~cm}$ & $2,0 \mathrm{~cm}$ & $1,8 \mathrm{~cm}$ & $2,3 \mathrm{~cm}$ & $2,0 \mathrm{~cm}$ \\
\hline 7 & $1,8 \mathrm{~cm}$ & $1,6 \mathrm{~cm}$ & $2,1 \mathrm{~cm}$ & $1,7 \mathrm{~cm}$ & $1,8 \mathrm{~cm}$ & $1,7 \mathrm{~cm}$ & $1,8 \mathrm{~cm}$ & $1,6 \mathrm{~cm}$ \\
\hline 8 & $1,5 \mathrm{~cm}$ & $1,4 \mathrm{~cm}$ & $1,9 \mathrm{~cm}$ & $1,7 \mathrm{~cm}$ & $1,7 \mathrm{~cm}$ & $1,6 \mathrm{~cm}$ & $1,7 \mathrm{~cm}$ & $1,5 \mathrm{~cm}$ \\
\hline 9 & $1,3 \mathrm{~cm}$ & $1,3 \mathrm{~cm}$ & $1,8 \mathrm{~cm}$ & $1,5 \mathrm{~cm}$ & $1,5 \mathrm{~cm}$ & $1,1 \mathrm{~cm}$ & $1,5 \mathrm{~cm}$ & $1,2 \mathrm{~cm}$ \\
\hline 10 & $1,3 \mathrm{~cm}$ & $1,0 \mathrm{~cm}$ & $1,7 \mathrm{~cm}$ & $1,3 \mathrm{~cm}$ & $1,3 \mathrm{~cm}$ & $1,0 \mathrm{~cm}$ & $1,4 \mathrm{~cm}$ & $1,0 \mathrm{~cm}$ \\
\hline 11 & $1,1 \mathrm{~cm}$ & $0.9 \mathrm{~cm}$ & $1,4 \mathrm{~cm}$ & $1,2 \mathrm{~cm}$ & $1,2 \mathrm{~cm}$ & $0.9 \mathrm{~cm}$ & $1,3 \mathrm{~cm}$ & $0.9 \mathrm{~cm}$ \\
\hline 12 & $1,0 \mathrm{~cm}$ & $0,8 \mathrm{~cm}$ & $1,3 \mathrm{~cm}$ & $1,0 \mathrm{~cm}$ & $1,1 \mathrm{~cm}$ & $0,8 \mathrm{~cm}$ & $1,2 \mathrm{~cm}$ & $0,8 \mathrm{~cm}$ \\
\hline 13 & $0.9 \mathrm{~cm}$ & $0.7 \mathrm{~cm}$ & $1.3 \mathrm{~cm}$ & $0,9 \mathrm{~cm}$ & $1,0 \mathrm{~cm}$ & $0.6 \mathrm{~cm}$ & $1.1 \mathrm{~cm}$ & $0.7 \mathrm{~cm}$ \\
\hline 14 & $0,8 \mathrm{~cm}$ & $0,6 \mathrm{~cm}$ & $1,2 \mathrm{~cm}$ & $0,7 \mathrm{~cm}$ & $0,9 \mathrm{~cm}$ & $0,5 \mathrm{~cm}$ & $1,0 \mathrm{~cm}$ & $0,6 \mathrm{~cm}$ \\
\hline \multicolumn{7}{|c|}{ Ket: Kiri $=$ tidak diberi daun kemangi } \\
\multicolumn{7}{|c|}{ Kanan diberi daun kemangi }
\end{tabular}

Pada hari ketiga luka pada punggung kelinci sama-sama masih terbuka, pada luka yang tidak diberikan daun kemangi terlihat luka berwarna kemerahan, masih agak basah, masih ada selaput tipis yang melapisi permukaan luka dan tepi luka yang tidak beraturan, sedangkan pada luka yang diberi daun kemangi terlihat luka berwarna gelap karena tertutupi oleh lumatan daun kemangi yang mengering.

Pada hari ketujuh, panjang luka pada punggung kiri dan kanan kelinci telah berkurang. Pada saat ini terjadi proses proliferasi, fibroblast mensintesis kolagen dan substansi dasar menjadi kolagen. Serat kolagen ini merupakan substansi protein yang menambah tegangan permukaan dari luka, jumlah kolagen yang meningkat akan menyebabkan bertambahnya kekuatan permukaan luka sehingga kecil, tarikan pada tepi luka. ${ }^{13}$ Pada penelitian ini didapatkan perbedaan panjang luka, terlihat pada kelinci $\mathrm{C}$, luka lebih cepat mengecil dengan ukuran luka $1,7 \mathrm{~cm}$ dibandingkan dengan kelompok kontrol dengan ukuran luka $1,8 \mathrm{~cm}$.

Pada pemeriksaan makroskopik hari keempat belas, luka pada kelompok kontrol 
dan kelompok perlakuan sudah mulai perbaikan, tetapi belum ada kelompok yang menutup sempurna. Pada penelitian ini, kelinci $C$ yang paling menunjukkan perbaikan, luka kontrol ukuran luka 0,9 cm, sedangkan luka perlakuan ukuran luka 0,5 cm yang ditutupi kerak berwarna hitam. Pada saat ini terjadi fase remodeling, kolagen yang terbentuk akan menyatu, menekan pembuluh darah dalam penyembuhan luka, sehingga bekas luka menjadi rata dan tipis. ${ }^{13}$

Berdasarkan hasil pengamatan dari penelitian ini, didapatkan bahwa luka yang diberikan daun kemangi tidak sama panjang dengan luka yang tidak diberikan daun kemangi. Luka pada punggung kanan atau luka perlakuan lebih cepat sembuh dibandingkan dengan luka yang tidak memiliki daun kemangi. Hal ini disebabkan oleh kandungan flavonoid pada daun kemangi yang berperan sebagai anti inflamasi yang dapat membantu proses penyembuhan luka.

\section{KESIMPULAN}

Dari hasil penelitian uji efek daun kemangi terhadap penyembuhan luka insisi pada kelinci didapatkan bahwa panjang luka yang diberi daun kemangi lebih cepat mengecil dibandingkan dengan panjang luka yang tidak diberi daun kemangi.

\section{SARAN}

1. Perlu dilakukan penelitian dengan penambahan subjek untuk hasil yang lebih akurat.

2. Perlu dilakukan pemeriksaan luka secara mikroskopik untuk melihat efek daun kemangi terhadap penyembuhan luka.

\section{DAFTAR PUSTAKA}

1. Oktora L. Pemanfaatan obat tradisional dengan pertimbangan manfaat dan keamanannya. Majalah Ilmu Kefarmasian. April 2006; Vol. III:1.

2. Prakash, Gupta S. Therapeutic uses of Ocimum Sanctum Linn (Tulsi) with a note on eugenol and its pharmacological action. Indian $\mathrm{J}$ Physiol Pharmacol 2005;49(2):126.

3. Adiguzel A, Gulluce $M$, Sengul $M$. Antimicrobial effects of Ocimum basillicum (Labiatae) extract. Turk J Biol 2005:155-160.

4. Joseph B. Ethanopharmacological and phytochemical aspects of Ocimum sanctum Linn-the elixir of life. British Journal of Pharmaceutical Research 2013; 3(2):274.

5. Mahmood S, Sidik K. Synergistic effects of alcoholic extract of sweet basil leaves and honey on cutaneous wound healing in rats. International Journal of Molecular Medicine and Advance Sciences 2005:220.

6. Moghaddam A, Syayegh J, Mikaili P, Syaraf J. Antimicrobial activity of essensial oil extract of Ocimum basilicum linn leaves on a variety of pathogenic bacteria. Journal of Medicinal Plants Research 2011;5(15):3454.

7. Haryani A, Grandiosa R, Buwono I, Santika A. Uji Efektivitas daun papaya untuk pengobatan infeksi bakteri Aeromonas Hydrophila pada ikan mas koki. Jurnal Perikanan dan Kelautan 2012; Vol. III:215.

8. Naibaho O, Paulina V, Yamlean, Wiyono W. Pengaruh basis salep terhadap formulasi sediaan salep ekstrak daun kemangi (Ocimum sanctum L.) pada kulit punggung kelinci yang dibuat infeksi Staphylococcus aureus. Journal Ilmiah Farmasi 2013;2(2): 28. 
9. Sjamsuhidajat, R. dan De Jong, W. Buku ajar ilmu bedah. Edisi ke-2. Jakarta: EGC; 2004. h 67

10. Syarfati K, Eriani, Damhoeri A. The potential of jarak cina (Jatropha multifida L.) secretion in healing newwounded mice. Jurnal Natural 2011;11(1):16

11. Reksoprodjo, Soelarta. Kumpulan kuliah ilmu bedah. Jakarta: Binarupa Aksara; 2006. h. 88.

12. Kumar, Cotran, Robbins. Buku ajar patologi Robbins. Edisi ke-7. Jakarta: EGC; 2007. h. 80.

13. Perdanakusuma, David. Anatomi fisiologi dan penyembuhan kulit. Plastic Surgery Departement 2007:5-7 